\title{
Financial Services Privatisation: Two Case Studies
}

\author{
John A. Consiglio ${ }^{1}$ \\ ${ }^{1}$ Department of Banking \& Finance, Faculty of Economics, Management \& Accountancy, The University of Malta, \\ Msida, Malta \\ Correpondence: John A. Consiglio, Ph.D., Department of Banking \& Finance, Faculty of Economics, Management \\ \& Accountancy, The University of Malta, Tal-Qroqq, Msida, Malta.
}

Received: July 30, 2018

Accepted: August 21, 2018

Online Published: September 16, 2018

doi:10.5430/ijfr.v9n4p63

URL: https://doi.org/10.5430/ijfr.v9n4p63

\begin{abstract}
How Romania's, and Estonia's, financial services sectors moved towards, and through, their respective privatisation processes provides sharply contrasting scenarios. For a long time Romania's following up of a promise made to the International Monetary Fund was simply an unimpressive record of dithering. By contrast, Estonia's performance was a generally positive account, one which was based on norms and structures which were often comparable to those in advanced industrial countries. This paper examines in detail these two national experiences.
\end{abstract}

Keywords: financial services privatisation, Romania, Estonia

\section{The History and Theory Revisited}

Privatisation now appears to have dropped way down in the public discourse in most countries, let alone the privatisation of specifically the financial services sector. However, how it evolved in different countries continues to be a fascinating theme for contemporary economic historians, and this researcher has carried out in-depth studies of the process as it evolved particularly in the post-1989 Central and Eastern European countries (CEECs). Barely a decade after joining the EU the CEECs are now often appearing as fanning discord within the bloc, even as their economies provide an interesting source of dynamism. (Mellow, C. 2016)

This paper presents two sharply contrasting CEEC examples of how financial sectors moved from total state ownership into the private sector. Romania, and Estonia, respectively located at the bottom and top geographical ends of the continent, were similarly distant in their dispositions and modalities towards effective change.

For many years Eastern Europe mirrored several key features of the Soviet command economy. The basic elements of this reflection were: firstly, the state (essentially meaning the Communist Party) owned and directed the economy. Secondly, land and mineral resources, provision of banking and all other financial services, commerce, and foreign trade, were all nationalised, and each overseen by state monopoly structures of various forms. Soviet-type 'single channel' banking replaced competitive commercial banks, with each channel bank undertaking a specific and different role, such as foreign trade, or investment, or saving. Thirdly, in stark contrast to Western market economies, economic management was such that primary production units - and services - exercised little autonomy. Fourthly, quantity was emphasised over quality. Fifth, whereas in the West money supply, the price mechanism, and credit, functioned in structures where they could serve as tools to reduce costs and boost productivity, here in the command economies these were either absent or ineffective. And, lastly, citizens and consumers had to endure innumerable deprivations, such as would be intolerable in the democratic West, and with also, naturally, exceptionally low financial services quality conceptions or notions. Ultimately all these elements cumulatively often sparked change, often revolutionary in nature, in the CEECs.

The banking systems of practically all the CEECs evolved from the centrally planned monobank systems. When the process of change began, different approaches were taken in these economies in transition (EITs) in the creation of two-tier banking systems, but all involved the hiving off of commercial banking activities from the former state monobanks, leaving independent central banks to pursue monetary policy and exchange rate strategy. State-owned commercial banks (SOCBs) were born as joint-stock entities, with predominant and often exclusive ownership of the shares placed in the hands of a state agency or agencies.

In Hungary the commercial portfolio of the National bank of Hungary (NBH) was divided along sectorial lines to create here such SOCBs. In the Czech Republic the commercial portfolio was separated from the Czechoslovak State 
Bank (CSB) in 1990, and three universal state-owned banks (SOBs) were born. In Poland the commercial portfolio of the National Bank of Poland (NBP) was divided on a regional basis to create nine such SOCBs. Existing specialised Polish banks (i.e. the foreign trade [merchant] bank and the state savings bank) were given universal charters, and restructured as joint-stock companies. In Bulgaria the creation of the two-tier banking system started in 1987 when the Bulgarian National Bank (BNB) occurred. In Estonia, as we shall see hereunder, it was after the Soviet perestroika period that the two-tier banking system started. A 1989 Soviet decree granted the Baltic states the right to organise independent banking systems. (Roberts Zile, et al, 2000)

"Bank privatisation" in these and other CEECs actually refers to the divestiture of state ownership in an existing joint-stock bank. As such, bank privatisation of SOCBs should be distinguished from the creation of new (from scratch) private banks. The state often retained a core-investor-size stake in privatised SOCBs. (Note 1) By contrast "banking sector privatisation" must be considered as government policy that encourages the entry of either new private banks, or foreign banks, as greenfield operations into an economy.

So the orchestrated transfer of ownership shares in existing banks from the hands of the state into private hands fits the concept of bank privatisation. Although both types of privatisation are related in establishing a market based banking sector, the two concepts should objectively deserve treatment within separate and distinct conceptual frameworks, an exercise which can be much handicapped if one follows only some of the facts which in themselves would be described as contemporary banking history evolution in these CEECs.

The main privatisation policies followed one, or some combination of, from the three methods of: voucher distribution, private placement with a strategic foreign financial investor (SFFI), or initial public offering (IPO). Hungary, the Czech Republic, and Poland, provided an interesting laboratory for all EITs as each used a method of bank privatisation that was broadly representative of one of these prototypes. Hungary used the SFFI method for two of its three main bank privatisations. The voucher mass-privatisation programme was the Czech method. In the case of Poland, after an eclectic approach that combined a search for a SFFI with an IPO, the Polish government settled on the IPO methodology as its preferred strategy for privatisation.

A fully detailed comparative analysis which includes all the CEECs and former states of the USSR, which tackles all the key issues of economic transition, and how they made progress in their respective national privatisation programmes, is an extensive exercise, and has featured in other of our studies. But it did not deter Colin Jones who in 1992 published a seminal work (Jones C., 1992) covering the challenges of privatisation in Albania, Armenia, Azerbaijan, Belarus, Bosnia-Herzegovina, Bulgaria, Croatia, the Czech and Slovak Republics, Estonia, Georgia, Germany, Hungary, Kazakhstan, Kyrgyzstan, Latvia, Lithuania, Montenegro Poland, Romania, Macedonia, Moldova, the Russian Federation, Serbia, Slovenia, Turkmenistan, Ukraine, and Uzbekistan. Jones's work showed that, for existing and potential investors in these parts of the world the important issues always warranting examination are:

- What were each region's objectives for privatisation of its banking sector;

- The scale and scope of the priorities involved (e.g. structures, bad loans, cronyism, corporate governance, technology (or indeed the absence of it!) and which needed to be taken into account; and

- Actual details of the privatisation methods and strategies being employed. (Note 2)

Although they shared the same form of government for over five decades these economies were anything but homogeneous, a fact which needs to be factored into account when individual regimes are analysed for pace, and sequencing, of financial services reform. Hungary and Poland were already some way down the reformist road when other countries in Jones's list had barely started the journey. The typical command economy was dominated by industry and agriculture, with services - including banking - only comprising around one-third of the whole, i.e. a situation which was the reverse of the usual Western structure.

But, inevitably there were variations of these evolutionary patterns. Even while the above may be considered a general structural background, one could also conceivably accept the existence of other considerations (e.g. geography, race and ethnicity, history in pre-communist dominance periods, religion and anthropology) as having, even in small measures, impacted upon how and when countries privatised. Our choice in this paper of two example case study countries - one from the Balkans and the other from the Baltic - for examination of their bank privatisation processes, must therefore be seen with all of the above as the general background.

\section{Romania}

The former Czechoslovakia was, for example, far more industrial than Romania. But in both cases the incidence of bad and/or doubtful debts in their banking systems was very high. Between 1988 and September 1990 accumulated 
losses exceeding Lei 250 bn were written off in Romanian enterprises, with the banks then being baled out from their weight through the issue of government deposits. In 1991 Government Decision No. 447 (subsequently Law 7/1992) provided further substantial government refinancing of non-performing enterprise loans (Lei $135 \mathrm{bn}$ ).

Romania formally launched its mass privatisation programme in 1992 by distributing privatisation vouchers to about seventeen million citizens, with the initially expressed objective being that of letting them acquire 30 per cent of the capital of the 6300 companies which the government wanted to see privatised. But nothing exciting really followed, least of all having any livening up of capital market structures or activity.

Capital markets activity returned to Romania in 1995 after a fifty-year absence. Whatever the shortcomings of the market, its opening and the announced mass privatisation programme - which aimed to sell off within a year of its launch some 3900 companies - freed a large part of the economy from state control. But, measured against the size of the economy, Romania had Central Europe's smallest stock market during the 1995-1999 period. Daily trading volumes on Romania's stock market in 1997 were a meagre \$2.8 million, with nearly all of this in about 50 companies. In terms of sheer numbers however both the Bucharest Stock Exchange and Resdaq (the OTC market) were made to look impressive: a total of 5000 companies with 100 on the Bucharest exchange. (BCE, 1998) In December 1997 the Romanian Bank for Development (RDB), actually one of the best SOBs and big in trade finance, was clearly indicated as one of the first to be privatised.

Early in 1998 Romania made a promise to the IMF that as part of its national economic programme it would privatise three of its SOBs (vide Table 1). The World Bank was also demanding that at least two SOBs be sold before it would release a final $\$ 100 \mathrm{mn}$ tranche of a finance sector structural adjustment loan. By most standards the country had one of the region's most ineffective banking systems. Bank lending as a share of GDP was less than $15 \%$, compared e.g. with $60 \%$ in the Czech Republic. The only way to improve was to import, via bank sales, foreign capital and knowhow: in short selling controlling stakes in the banks to strategic investors.

Table 1. Romania SOBs - Lei bn - end 1996

\begin{tabular}{llll}
\hline & Assets & Deposits & Profits \\
\hline Banco Agricola & 8,120 & 2,500 & 170 \\
\hline Bankcoop & 2,160 & 1,180 & 56 \\
\hline Bancorex & 12,980 & 4,100 & 170 \\
\hline BankPost & 1,240 & 270 & 32 \\
\hline RCB & 8,700 & 2,720 & 610 \\
\hline RDB & 3,760 & 700 & 460
\end{tabular}

Source: Price Waterhouse (BCE, Mar 1998)

The 'merchandise available for sale' was indeed a mixed bag. Banc Post (post office bank) and RDB were saleable as they were relatively clean and small. Bank Post had 108 branches and outlets in about 2000 post offices, a retail presence making it attractive as a distributor of products such as insurance. Most of its business was short-term lending, often backed by export guarantees. And its management, by dint of its correspondent banking relationships, also had some international experience.

The third bank earmarked for privatisation was Banco Agricola whose asset base was almost twice that of the other two together. In the particular context of the Romanian economy (Note 3), with an extremely poor and predominantly agricultural working population eking out a bare living on the basis of state farming subsidies, this SOB was the traditional vehicle for financing, but was also loaded with bad debts. It was highly unlikely to attract interest without parliament voting a proposal to clear these.

The EBRD, and the World Bank's IFC, were prepared to take stakes in three Romanian banks on the basis of loan-for-shares agreements. The EBRD was very active in all the Eastern European banking sectors, and all along leading personalities in the country were confident that it would play a useful role in Romania too. (Lieven, A., \& Cook, J., 1998) In its 1999 Transition Report (p. 256) thew EBRD highlighted the fact that Bancorex had been out under administration of the National Bank of Romania (NBR) at end of February 1999 when more than $70 \%$ of the bank's loans were classified as non-performing. 
Table 2. The structure of the Romanian banking system as of end-December 1998

\begin{tabular}{|c|c|c|c|c|c|}
\hline \multirow{2}{*}{$\begin{array}{l}\text { Capital } \\
\text { Ownership }\end{array}$} & \multirow{2}{*}{$\begin{array}{l}\text { Number of } \\
\text { banks* }\end{array}$} & \multicolumn{4}{|c|}{ As a share of } \\
\hline & & $\begin{array}{l}\text { Balance } \\
\text { Sheet }\end{array}$ & $\begin{array}{l}\text { Total } \\
\text { Credits }\end{array}$ & $\begin{array}{l}\text { Total } \\
\text { Deposits }\end{array}$ & $\begin{array}{l}\text { Paid-up } \\
\text { Capital }\end{array}$ \\
\hline State owned & 1 & 9.56 & 5.43 & 13.05 & 4.38 \\
\hline Majority state-owned & 6 & 68.70 & 76.11 & 63.22 & 55.36 \\
\hline Domestic private capital & 4 & 3.29 & 3.85 & 3.96 & 4.84 \\
\hline Domestic \& private capital & 6 & 6.10 & 5.92 & 5.79 & 7.02 \\
\hline $\begin{array}{l}\text { Majority (domestic \& foreign) } \\
\text { private capital with some } \\
\text { state-owned capital }\end{array}$ & 1 & 1.74 & 2.14 & 2.22 & 1.59 \\
\hline $\begin{array}{l}\text { Majority domestic private \& } \\
\text { state-owned capital }\end{array}$ & 1 & 0.21 & 0.18 & 0.16 & 1.00 \\
\hline $\begin{array}{l}\text { Majority (foreign \& domestic) } \\
\text { private with some state- } \\
\text { owned capital }\end{array}$ & 1 & 0.69 & 0.82 & 0.85 & 1.46 \\
\hline $\begin{array}{l}\text { State-owned \& foreign } \\
\text { private capital }\end{array}$ & 1 & 2.13 & 0.62 & 2.40 & 6.88 \\
\hline $\begin{array}{l}\text { Domestic \& foreign } \\
\text { Private capital }\end{array}$ & 5 & 2.64 & 1.65 & 2.97 & 5.41 \\
\hline Foreign private capital & 8 & 4.94 & 3.28 & 5.38 & 12.06 \\
\hline & 34 & 100.00 & 100.00 & 100.00 & 100.00 \\
\hline
\end{tabular}

*Except Dacta Felix and Credit Bank.

Note: The NBR Quarterly Bulletin 1/1999 features a full list of the 45 banks operating in Romania at $31^{\text {st }}$ March 1999, 36 being shown as Romanian legal entities and 9 as foreign.

Source: National Bank of Romania, Annual Report, p.75

The management of Bancorex had resigned in a dispute with the government over the terms of a restructuring plan, leading to a run on the bank, with some $\$ 200 \mathrm{mn}$ fleeing out of the country's banking system. The development of a restructuring plan for Bancorex too had featured prominently amongst the "prior actions" required of the government under the IMF programme under negotiation. The State Ownership Fund owned $62 \%$ of the bank, with the rest held privately by financial investment companies (formerly private ownership funds) and some individuals. (Note 4)

An Asset Recovery Agency was created to manage Bancorex's non-performing loan portfolio, and to implement recovery action. In July 1999 Bancorex's licence was withdrawn, and by this time the country's overall banking system was defined in terms of the structure in Table 2 above. Besides the EBRD, interest in BankPost was also shown by the Anglo-Dutch joint venture ABN Amro Hoare Govett who were confident that they could meet government's demand for a trade sale and equity placement (domestic and international) by end of 1998 .

But, again, as was in fact also the case of the Czech Republic, the view of Western analysts of the Romanian government's resoluteness on privatisation was anything but positive for a long term. Even as a new 1998 programme promised calls for at least 1600 companies to be privatised in that year, including three banks, uncertainty prevailed. (Note 5) The causes for this uncertainty were varied:

- $\quad$ Reported plans to actually sell the stakes in BankPost to employees, to the post office, and to national telephone monopoly Romtel;

- $\quad$ Expressed intentions to retain 'golden shares' and lack of clarity on the size of these(Cook, J., 1998); 
- The little real power held by the investment banks mandated to make the privatisations beyond getting bids on board; and, of course

- The usual problem of bank privatisation touching the darker side of nationalism, where politicians were reluctant to put into the hands of foreigners what they considered to be a key part of their power.

For a long time Romania's failure to deliver on promises of economic reform earned for it a reputation of the laggard of Eastern Europe. (Note 6) The centre-right coalition that ruled from 1996 till the end of 2000 paid scant heed to budget discipline, and tolerated inflation that never went below 40 per cent. Privatisation proceeded so slowly that after a decade 80 per cent of large SOEs still remained unsold, and allegations of corruption tainted many that were made. Between 1997 and 2000 GDP fell by 13 per cent. One could hypothetically argue that it was the problem of coordination among institutions in the privatisation process which hampered national economic progress for a very long time and this when there were, from 1997 onwards, several indicators of an increased pace of legislation and marketing measures(Note 7) related to the process.

Certainly Romania's extremely bleak economic situation in 1998 and 1999 had "at the root of the whole mess a state banking sector that could soon come apart at the seams". (BCE, 1999) Similar to, for example, Pakistan, Russia, and the Ukraine, it was hovering on the brink of defaulting on Eurobond loan repayments even as - surprisingly contrary to IMF rules - it kept repaying big chunks of them. This too can in a way be interpreted as the country clinging on to post-communist economic practices, when in fact the country, along with Czechoslovakia but different to most other new post-communist governments, did not inherit large external debts from the predecessor governments. (Aldcroft, D. H., \& Morewood, S., 1995)

The EBRD Transition Report for 2000 saw the July 1999 closure of Bancorex as helping to improve the financial performance of the banking system. The share of non-performing loans fell by 50 per cent between May and December 1999, but continued government support to weak enterprises added a further US\$1.3 bn (equivalent to 3.8\% of GDP) to the domestic debt. As tighter enforcement of Basle and EU-standard regulation bit in, several private banks started to fail, but still this exit process was slow. The Romanian Religion's Bank was put under special supervision in May 2000 after it was unable to raise capital.

The scenario continued to worsen. In May 2000 the largest Romanian investment fund (FNI) too collapsed after mismanagement and fraudulent practices as well as poor regulatory oversight. The failure of FNI also involved the state-owned Savings Bank (CEC) which was a shareholder in FNI's management company, and which had invested in FNI certificates and issued a guarantee for investments in it. This collapse put pressure on the largely unregulated "popular banks", which were mostly credit cooperatives not having any deposit insurance protection for their depositors. Banca Popular Romana, the largest of such cooperatives ceased to operate in June 2000 when it could not meet deposit withdrawal requests.

Even as the central bank stepped in, in July 2000, to take over the authorising, regulating, and monitoring of funds, suspending the issue of all new such licences, it was the turn of the State Ownership Fund (SOF) itself - the country's main privatisation authority - to reach the end of the road in September 2001. It too was in a mess. It still held many shareholdings in 1047 firms that needed to be privatised, or closed. But, worse than that, several of its past divestitures were coming back to haunt it in the shape of controversy and corruption accusations. And these included some of the biggest amongst its past sales. (Note 8) Under attack from all quarters it closed down with the remaining SOEs sinking deeper and deeper into debt, and in early 2001 was replaced by a new body, the Authority for Privatisation and Management of State Assets (APAPs).

When Adrian Nastase came in as Prime Minister at the end of 2000 he showed no hesitancy in declaring his intentions to jump-start the country's stalled privatisation programme. His first big promises were to jointly go for deficit reduction and privatisation, hoping to end a decade of dithering over reform. At end-2000 SOBs accounted for $38 \%$ of registered capital, and held about half of the domestic market in terms of assets. (ECB, 2001) In the first nine months of 2001 GDP was up 5 per cent, industrial production grew by $10 \%$, and inflation dropped to below $10 \%$. Besides selling Sidex (a large steel mill on the Danube) to the LNM Group (the Anglo-Indian conglomerate which owned the world's fourth largest steelmaker) he vowed to move ahead with plans to find by early 2002 a strategic investor for Banca Commerciale Romana, which was then Romania's largest bank.

In April 2001 Banca Agricola was privatised to a consortium which included Raiffeisen Bank and the Romanian American Enterprise Fund. After that privatisation only three banks remained state-owned. The Banca Agricola privatisation brought a situation where overall more than two-thirds of total assets of the banking system were now 
in private hands and about $55 \%$ were foreign owned (c.f. with a situation of $78 \%$ being state-owned at end-December 1998).

Table 3. Romania - banking sector ownership

\begin{tabular}{llllll}
\hline & $\mathbf{1 9 8 9}$ & $\mathbf{1 9 9 4}$ & $\mathbf{1 9 9 9}$ & $\mathbf{2 0 0 0}$ & $\mathbf{2 0 0 1}$ \\
\hline Number of banks & 12 & 27 & 41 & 41 & 41 \\
\hline $\mathbf{1 0 0 \%}$ state-owned & 5 & 1 & 1 & 1 & 1 \\
\hline Partially state-owned & - & 6 & 3 & 3 & 2 \\
\hline $\mathbf{1 0 0 \%}$ private & - & 20 & 37 & 37 & 38 \\
\hline
\end{tabular}

Source: BCE

Of the three remaining SOBs the most attractive to investors was Banca Commerciala Romana (BCR), which held 30 per cent of total banking system assets and total loans to customers. In 2001 the usual appointment of an apposite privatisation commission for this bank was made, but, again, government dithered and moved the plan to complete the sale to before the end of 2002. The strategic ownership structure of Romania's banking sector in 2001 then stood as follows (Table 4).

Table 4. Romania - strategic ownership of banks - 2001 (On Adjusted Common Equity (ACE) basis) *

\begin{tabular}{|c|c|c|c|c|c|}
\hline \multirow[b]{2}{*}{ Bank } & \multirow[b]{2}{*}{$\begin{array}{l}\text { Ranking among } \\
\text { Top } 100 \text { CEEC } \\
\text { banks }\end{array}$} & \multirow[b]{2}{*}{$\begin{array}{l}\text { Total reported } \\
\text { assets US\$ mn }\end{array}$} & \multirow[b]{2}{*}{ Main shareholder } & \multicolumn{2}{|c|}{$\%$ of all } \\
\hline & & & & $\%$ & $\begin{array}{l}\text { Foreign } \\
\text { investors } \\
\text { in capital }\end{array}$ \\
\hline $\begin{array}{l}\text { Banca } \\
\text { Commerciale } \\
\text { Romana }\end{array}$ & 7 & 2353 & State & - & - \\
\hline $\begin{array}{l}\text { Banca Romana } \\
\text { pentru } \\
\text { Dezvolatare }\end{array}$ & 25 & 1355 & Societe' Generale (FR) & 51 & 56 \\
\hline Bank Post SA & 54 & 367 & 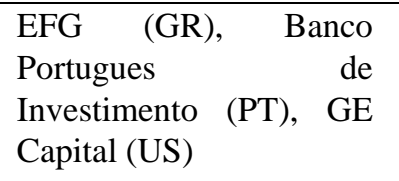 & 53 & 53 \\
\hline $\begin{array}{l}\text { Commercial } \\
\text { Bank Ion Tiriac }\end{array}$ & 84 & 283 & Redrim Intnl Investments & 40 & 76 \\
\hline Banca Agricola & 96 & 313 & State & - & - \\
\hline $\begin{array}{l}\text { FR = France; GR } \\
\text { For banks \& } \\
\text { Non-performing I }\end{array}$ & $\begin{array}{l}=\text { German; PT }=\mathrm{Po} \\
\text { ank holding com } \\
\text { oans. }\end{array}$ & $\begin{array}{l}\text { ugal; US = Unite } \\
\text { anies. Common }\end{array}$ & $\begin{array}{l}\text { States } \\
\text { Equity adjusted for Loan }\end{array}$ & Loss & eserves \& \\
\hline
\end{tabular}

Sources: Standard \& Poor's; Central Bank

Again, in the case of the former savings bank $C E C$, dithering continued on whether it would be given pure commercial bank status in the subsequent years, whilst Eximbank still needed 'surgical' restructuring before privatisation could even start. But even as this hesitation persisted, the branches of foreign banks in Romania (Note 9) - operating in terms of legislation that now allowed them to enter the market under the same conditions as the domestic banks (NBR, 1992) - these were now very effectively making their presence on the market.

But this factor, "the market", was now carrying with it a public, political, indeed psychological connotation totally different to the past. By 2004 Romania, along with neighbouring Bulgaria, was deeply involved in negotiations for 
entry into the European Union. The country's accelerating privatisation drive was seen, and actively pursued, in terms of the necessity that the country be pronounced by the EU as actively seeking to satisfy that criterion (one of four) of the Copenhagen requirements, viz that of the country being a "functioning market economy" (Note 10). Some 70 per cent of Romanian GDP was now being created by the private sector, and that earned it the status of a market economy.

German Chancellor Gerhard Schroeder, with what could be described as perceptible political astuteness, held that it would be considered as a functioning market economy "if privatisation continues at the pace seen recently". (Reuters, 2004) Such urging on was conceivably motivated not solely by any wish to see EU expansion, but also by perceived prospects of more German involvement with an (eventually) totally privatised Romanian economy. Even as Schroeder spoke, the German bank $K f W$ was active in asserting a financing presence in relation to significant deals worth some $€ 800$ million for German firms (Note 11) in the Romania market. In some sense Romania had "arrived"!

\section{Estonia}

This Baltic economy's banking privatisation was a very different story to tht of Romania, evolving indeed with a different conceptual approach. Eesti Pank (EP) Estonia's central bank (Note 12) claims that Estonia "was the country where the very first privately owned commercial banks in the former USSR (and probably even the very first in the whole of Eastern Europe) were founded in the late Eighties. By the time of the 1992 monetary reform most of the country's 40+ banks were privately owned institutions that were not successors of any former state owned structures" (Kaja Kell, 1999). The EBRD places the number of commercial banks which were established between 1989 and 1992 at 42, adding that these were mostly small and undercapitalised (EBRD, 1994).

In some cases various Estonian state institutions had obtained minority holdings of these new commercial banks' shares. Eesti Pank statistics then considered bank shares held by government owned enterprises as state-owned shares. But what could conceivably be considered as a generally positive sounding scenario hides a lot.

The 1992 to 1995 years were "crisis" years for Estonian banking. (Note 13) It was a period when insolvent commercial banks held some $41 \%$ of the banking system's assets. The licences of five banks were revoked, two major banks were merged and nationalised, and another two large banks were merged and converted into a loan recovery agency. Although in early 1994 it seemed as if problems had been resolved, yet another two large banks were found to be insolvent, and again merged and converted to the national loan recovery agency.

It was palpably clear that the loss of trade with the Soviet Union which had happened in 1990 had caused a terms of trade shock for the country. Monetary policy was tightened, a currency board instituted, and 1992 and early 1993 was a sharp recession period. Did the recession bring the banking crisis, or did the banking problems of the country exacerbate the downturn? This is a debate which is still out amongst that country's banking historians.

The new currency board arrangements protected monetary policy from expansion in sequence to the banking problems. As the economy relied more heavily on cash payments, the currency-to-deposit ratio rose, and the money multiplier, fell. The exchange rate, pegged to the Deutsche Mark, was not affected.

At the start of this crisis period Estonia's banking system was a concentrated one. There was no direct foreign competition, and only joint ownership was permitted. With such non-diversification the banks often extended insider loans to owners. Credit assessment skills were underdeveloped, and weak accounting systems, plus inadequate loan classification and bad debt provisioning practices, were prevalent.

Estonian banking had been part of the Soviet monobanking system until the late 1980s, and the country had in fact participated in the bank reforms of the last years of the Soviet Union. (Note 14) In 1992 the Estonian banking system had become independent of the former Soviet system, and the Estonian currency (the kroon, or crown) was established in June 1992. In that year its value to the US\$ stood at 12.91, rising to 11.46 by 1995 , and dropping to 16.82 (15.66 to the Euro) in December 2000 (The Economist, 2001), certainly at least one consequence of the then ongoing crisis, and in which the banking sector was inevitably embroiled.

Eesti Pank (the central bank) placed the start of the crisis in November 1992. (Eesti Pank, 1993) The fact that three of the largest banks, Tartu Kommerspank (TK) (Tartu Commercial Bank), Balti Chispank (BC) (Union Baltic Bank), and Pohja-Eesti Akstapank (PEP) (North Estonian Bank), plus eight smaller banks (in 1993), became insolvent, well this considerably weakened public trust in the Estonian banking community. The government/central bank rescue operation merged $B C$ and PEP into a new bank Pohja-Eesti Pank (North Estonian Bank), and this was a complicated affair, particularly in view of the fact that $63 \%$ and $64 \%$ of the assets of the two respective banks were frozen accounts with the former Vneshekonomobank of the Soviet Bank. 
The Savings Bank of the USSR had had a branch in Estonia for a long time. An EP decision of the $14^{\text {th }}$ April 1992 turned that into Hoiupank, the Estonian Savings Bank, with the central bank owning all the shares. At that time 85\% of the population's savings were held by this bank and EP took over a debt claim against the former State Bank of the USSR for 3.05 bn roubles. The new bank was fully recapitalised on the basis of the central bank's gold reserves by the time of the monetary reform.

Consonant with its already mentioned policy of direct, but always well thought out, involvement in the region's banking systems, the EBRD became a minority shareholder in the Estonian Investment Bank in 1993. EP was the majority owner of this bank whose main role was the provision of currency loans to Estonian firms. In that year the American Baltic Bank started operations (Note 15), but several Russian and Ukranian banks' approaches for licences were being back-peddled as political resistance to Russian influence over the Estonian economy prevailed. Fear against possibility of involvement in money laundering, and fraud, from these sources was also high.

The IMF considered the licensing structures for banks as existing in Estonia between 1992-1995 as weak. Capital requirements for new banks were inadequate, and other prudential regulations were lacking. Supervision was inadequate and allowed for reckless fast growth, risky portfolios, and other mentioned shortcomings. (Lindgren, C. J., Garcia, G., Saal, \& M. I., 1996) An anti-regulation culture pervaded amongst many bankers and other economic operators, and for a long time during the period of banking problems in the early 1990s no system of deposit insurance was in place, and depositors simply suffered losses when banks failed. (Note 16) But 1993 must also be considered as having been a year where valuable bases for a later effective regulatory environment were laid down: it was the year when new banking regulations were brought in, a securities market law was enacted, a Securities Commission established, competition law passed and a competition agency established, and some utilities regulation (e.g. a new law on the electricity sector) was enacted.

A few months after the establishment of Hoiupank, four banks were invited to participate in a competitive tender to subscribe to new shares being issued. That October 1992 call brought in Hansapank as a strategic investor. The share capital was gradually increased after that, and by end 1995 EP only held $24.1 \%$ of the shares. This savings bank is the only bank in Estonia where one comes across privatisation in the restricted sense of privatising of former socialist structures.

EP is particular in distinguishing Hoiupank from the category of privately held problem banks which would first have been acquired by state structures and then sold at a later date. (Note 17) Bonin (1998, p 126) describes Hanspank's presence in Estonia as "a rare successful case of indigenous bank development within the four year old Estonia financial market. Not only did it become the largest domestic bank, but by acquiring 30 per cent of Hoiupank it dominated the market. Since Estonia was the most open financial market of the region's EITs (probably mainly because of the mentioned currency board) external competition could still prevent a monopolistic situation.

Special characteristics in fact made Estonia's financial markets (particularly the retail and interbank markets) different from those in other CEECs. In essence these were:

\section{The openness of the economy and of the financial system:}

Cross-border banking was a real option for retail and corporate bank customers, thus rendering local market structure less important than in other CEECs.

\section{Small individual household deposits in the banks, and high household wealth held in cash:}

A much smaller share of household deposits than in other former centrally planned economies was in the banking system, and Hoiupank was therefore far from "dominant" in the market (Note 18). This was a salient element of the Hansabank-Hoiupank marriage.

\section{The very short maturity of financial assets:}

The share of demand deposits was overwhelming: 82\% of total deposits in May 1995. The domestic supply of medium to long-term loanable funds was therefore extremely limited, and most such long-term loans were backed by foreign (mostly official) funds. Intermediation between domestic savers and borrowers was for far too long of secondary importance.

\section{Banking had a high, and rising, predominance in the financial markets:}

The four largest banks (Hansabank, Union Bank of Estonia, ESB and North Estonian Bank) had a combined overall market share of 68.4\% in May 1995. The 1992 bank crisis, the 1994 collapse of Social Bank, and increased minimum capital requirements, further increased the degree of market concentration and bias towards the banks. 
Estonian official policies placed no specific restrictions on foreigners making approaches for local businesses, but at evaluation stage strong study of an "entire bid" would take employment and investment size into consideration (EBRD, 1994). Between 1993 and 1995 FDI into the country moved up from \$ $153 \mathrm{mn}$ to $\$ 249 \mathrm{mn}$ in 1994, and down to $\$ 196 \mathrm{mn}$, but at that level was still one of the highest per capita inflows in the region.

A useful result from EP, and from the government's measures after the November 1992 crisis - (in essence merging of key banks, absorption of bad loans by government to cover liquidity shortfalls, and bank behaviour reorientation towards risk analysis and diversification, and away from speculation) - was customer shift patterns and more careful selection of banks. This both strengthened competition, as well as pushed the reformed banks to levels of confidence where external perception of Estonian banks - particularly in the eyes of Latvian and Lithuanian banks increasingly became that these were arrogant banks. But Estonia had implemented the most austere financial reform in the region (Note 19), reformed its banking three to four years ahead of its neighbours, and its banks had emerged as high-tech and hungry for international expansion.

A stock exchange (of sorts, it must be said!) was opened in Tallinn in 1996. It traded only five stocks at inception, but the step did indicate an important development in Estonian financial market reform, increasing transparency and opening equity investment to Western investors. The first year of this exchange was a hard and testing period. Investors were clearly worried about the fast pace of economic growth and a widening current deficit.

In one week in October 1997 the Talinn stock exchange plummeted a full $22 \%$, and again a further $60 \%$ in November 1998, and speculative pressure against the kroon was only resisted through continued expression by the central bank of its determination to support the currency board regime, which had fixed the rate to the D-mark at 8:1 for the full previous five years.

But even after the Estonian stock exchange had managed to bounce back late in 1997, it was only several years later that the real local interest in the exchange got into its stride. Up to around 1998 the Estonian capital markets remained small, and the only traded securities were central bank (EP) short-term bills. The first Estonian Eurobond issue by Eesti Uhispank in February 1999, appeared to do little to liven up securities market activity, and the EBRD, in its Transition Report for 2001 (p 138), was still expressing the hope that the consolidation of the Tallinn and Helsinki stock exchanges, the introduction of new securities legislation, and the development of domestic pension funds, would spur expansion of such security activity.

In Estonia, (unlike for example in Hungary), the central bank had strong statutory discretion over bank insolvency. But what is also cited in international policy debate is that its 1992 handling of the earlier mentioned bank failures was effectively a hands-off approach that paid off spectacularly. One reason which is today quoted by old, or experienced, Estonian bankers as a possible explanation for this is that, as some of the country's large commercial banks were inherited from the Soviet era as Estonian branches of the Soviet specialised banks, and as some of these had become partly owned by private Russian structures as their own parent banks went through an ownership transformation, for these reasons treating them severely would have had a strong political dimension, and a more laissez-faire attitude was "easier" to implement by the Estonian authorities.

Privatisation policy was therefore very substantially different in Estonia when compared to other CEECs. The predominant approach can be described as having been that of state structures only intervening to acquire privately held problem banks, to then sell them off later. The central bank became a holder of various small problem banks' assets over the years until these were all acquired by Eesti Uhispank (Union Bank) in early 1997.

In late 1998 the central bank (which had held no significant blocks of bank shares for the previous year) had to take over the majority (58\%) of the shares of Optiva Bank which then held an approximate 6.5\% market share. Plans were already in hand to sell them off by late 1999 or early 2000. Table 5 below shows that at end of 1998 the government only owned $14.3 \%$ of total ownership of Estonian credit institutions.

Table 5. Estonia - owners of credit institutions as of $31^{\text {st }}$ December 1998

\begin{tabular}{|c|c|c|c|c|c|c|c|c|c|c|}
\hline & \multicolumn{5}{|c|}{ Estonian legal persons } & \multicolumn{5}{|c|}{ Non resident legal persons } \\
\hline & $\begin{array}{l}\text { Public } \\
\text { Sector }\end{array}$ & $\begin{array}{l}\text { Credit } \\
\text { institution } \\
\mathrm{s}\end{array}$ & $\begin{array}{l}\text { Investme } \\
\text { nt funds }\end{array}$ & $\begin{array}{l}\text { Other } \\
\text { legal } \\
\text { persons }\end{array}$ & $\begin{array}{l}\text { Estonian } \\
\text { natural } \\
\text { persons }\end{array}$ & $\begin{array}{l}\text { Credit } \\
\text { institutio } \\
\mathrm{ns}\end{array}$ & $\begin{array}{l}\text { Investme } \\
\text { nt funds }\end{array}$ & $\begin{array}{l}\text { Other } \\
\text { legal } \\
\text { persons }\end{array}$ & $\begin{array}{l}\text { Foreign } \\
\text { natural } \\
\text { persons }\end{array}$ & Other \\
\hline $\begin{array}{l}\text { Eesti } \\
\text { Kredidipa }\end{array}$ & & & & $2.9 \%$ & $52.7 \%$ & & $9.1 \%$ & $27.0 \%$ & $0.0 \%$ & $8.3 \%$ \\
\hline
\end{tabular}




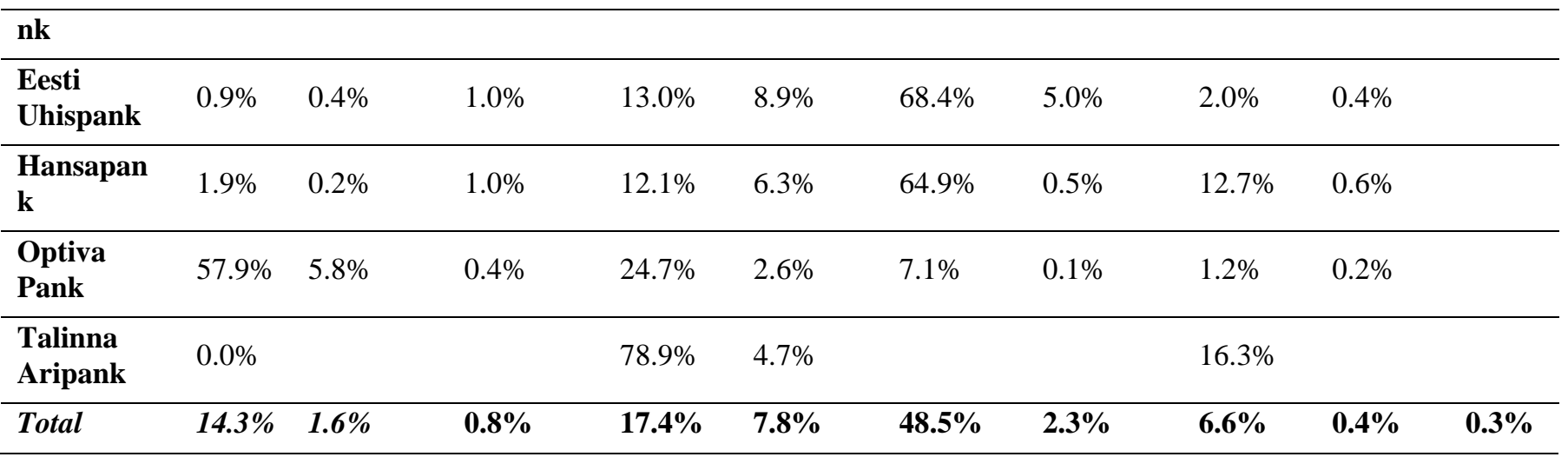

Source: Eesti Pank, Annual Report, 1998

Hansabank (Estonia's largest commercial bank), Estonia Savings bank (third largest, and largest as retail bank), Talinna Pank (fifth largest bank) (Note 20). Forekspank (another large commercial bank), and Uhisbank, all of these institutions had by 1998 become very ambitious institutions in the region. By international standards they were still small (and in certain respects backwards) but the benefits of early reform had placed them in a situation where they were even being looked upon with some hope (Schultz, T., 1996) that their discipline and propensity towards international expansion would possibly help sort out some of the chaos in the region's banking.

The evolution of ownership of Estonian banking between 1993 and 1998 emerges very clearly from the following Table 6.

Table 6. Estonian Bank ownership 1993-1998

\begin{tabular}{llllllll}
\hline & & $\mathbf{1 9 9 3}$ & $\mathbf{1 9 9 4}$ & $\mathbf{1 9 9 5}$ & $\mathbf{1 9 9 6}$ & $\mathbf{1 9 9 7}$ & $\mathbf{1 9 9 8}$ \\
\hline Total no. of banks & 21 & 22 & 18 & 15 & 12 & 6 \\
\hline $\begin{array}{l}\text { No. of banks with } \\
\text { exceeding 50\% }\end{array}$ & state ownership & 3 & 3 & 1 & 1 & 0 & 1 \\
\hline $\begin{array}{l}\text { No. of banks with foreign ownership } \\
\text { exceeding 50\% }\end{array}$ & 1 & 1 & 4 & 3 & 3 & 2 \\
\hline
\end{tabular}

Source: Eesti Pank, 1999

1997 was an extraordinarily good year for Estonian banks. These were now institutions which had embraced cutting-edge technology in their desire to become effective and profitable western style institutions. Paper cheques were never really introduced in Estonia: the PC, internet, telephone banking, and bank cards (Note 21), were the generally used fund flow systems, and when the banks in 1997 borrowed abroad at favourable rates, costs for domestic consumers fell. Bank assets and credit grew rapidly in that year, and record profits were made from securities trading. But the expansion of domestic credit financed by foreign borrowing raised concerns of economic overheating.

In 1999 the Estonian finance ministry granted the country's first-ever pension fund licence to Hansa Asset Management, a subsidiary of Hanspank. Inflation-boosting tax incentives to industrial investors and corporates attracted counter central bank intervention on the banks to raise CA ratios.( BCE, 1999) From 12 in 1997 the number of licensed banks dropped to five.

Over the 1998-99 years a number of banks merged. Hanspank joined with Hoiupank. Unispank joined with Talinna Pank, and Swedbanken acquired an influential stake in Hansabank (just under 50\%). Skandinaviska Enskilda Banken (also Swedish) acquired a significant minority stake in Ohispank (36\%), and a number of banks also closed. In late 1998 the central bank had recapitalised Forkesbank which had been going through a troubled patch, and then merged it with the Estonian Investment Bank. Early in 1999 in the aftermath of the Russian crisis, Evea Pank and ERA Pank (which actually owned 35\% of Evea Pank) were declared bankrupt. 
In June 2000 the central bank agreed with the Finnish Sampo Finance for the sale of its 58\% stake in Optiva Pank, then the third largest Estonian bank. Under this privatisation deal Sampo Finance paid a total of Ek 214 mn (approx $€ 14 \mathrm{mn}$ ), but also wrested a partial indemnity from EP to cover the quality of Optiva's assets. Sampo also offered to purchase the rest of the Optiva shares owned by minority shareholders - including the 19\% stake of Eesti Uhispank, then the country's second largest bank - for a price of Ek 7.8 per share.

With the sale of Optiva Pank the Estonian government and central bank reached the stage where - excepting some small residual holdings of less than 1 percent - the state had no more shares in the banking sector. A decade of single-minded reforms had not only brought its banks to age on the domestic front, but also in the region. Hansabank Latvia, the name given to Deutsche Lettische Bank - after Estonian Hanspank had bought it out in mid-1996 - by 1999 became Latvia's sixth largest bank. And it was now planning a subsidiary also in Lithuania. Hoiupank also bought the small Moscow-based bank FABA in September 1997.

Table 7. Estonian banking 1989-2001

\begin{tabular}{|c|c|c|c|c|c|}
\hline & 1989 & 1994 & 1999 & 2000 & 2001 \\
\hline Total No of banks & 10 & 22 & 7 & 7 & 7 \\
\hline 100 SOBs & 5 & - & - & - & - \\
\hline Partly SOBs & 0 & 1 & 1 & 0 & 0 \\
\hline $100 \%$ privately owned & 5 & 21 & 6 & 7 & 7 \\
\hline Commercial banks & 5 & 20 & 6 & 7 & 7 \\
\hline Investment banks & 0 & 1 & 0 & 0 & 0 \\
\hline Bank branches & $\mathrm{n} / \mathrm{a}$ & $\mathrm{n} / \mathrm{a}$ & 296 & 205 & 211 \\
\hline * Total deposits & $\mathrm{n} / \mathrm{a}$ & & 1681.4 & 2217.0 & 2719.7 \\
\hline * Total lending & $\mathrm{n} / \mathrm{a}$ & 279.7 & 1704.3 & 2189.2 & 2602.2 \\
\hline * Share Capital & $\mathrm{n} / \mathrm{a}$ & 34.1 & 134.2 & 123.7 & 130.5 \\
\hline Return on Equity (\%) & $\mathrm{n} / \mathrm{a}$ & 4.4 & 9.6 & 8.3 & 20.9 \\
\hline Loans overdue for 60 days (\%) & $\mathrm{n} / \mathrm{a}$ & $\mathrm{n} / \mathrm{a}$ & 3.4 & 2.2 & 2.7 \\
\hline
\end{tabular}

Source: Eesti Pank 2002

The last act in the Estonian state's total withdrawal from ownership of financial market structures was the May 2001 sale of its majority shareholding in the Talinn Stock Exchange to the owners of the Helsinki Stock Exchange. The EBRD described this as "consolidation" of the two exchanges, and expressed the view that, together with new securities legislation and the development of pension funds, this measure "should spur the expanding of securities activities".( EBRD, 2001)

At the end of 2000 the Talinn exchange market's capitalisation stood at $€ 1.9$ billion, compared to $€ 318$ billion and $€$ 32.9 billions of, respectively, the Helsinki and Warsaw exchanges. And at the end of 2001, in terms of CEEC strategic ownership status, Estonia's banks ranked, and were owned as follows:

Table 8. Estonia - strategic ownership of banks - 2001 (on Adjusted Common Equity (ACE*) basis)

\begin{tabular}{llllll}
\hline Bank & $\begin{array}{l}\text { Rating } \\
\text { among top } \\
\mathbf{1 0 0} \text { CEEC } \\
\text { banks }\end{array}$ & $\begin{array}{l}\text { Total } \\
\text { reported } \\
\text { assets } \\
\text { US\$mn }\end{array}$ & Main shareholders & Holding \% & $\begin{array}{l}\text { \% of all foreign } \\
\text { investors } \\
\text { capital }\end{array}$ \\
\hline Hansabank & 14 & 313 & Smedbank (SE) & 58 & 100 \\
\hline Eesti Huisbank & 15 & 925 & SEV (SE) & $>96$ & - \\
\hline
\end{tabular}




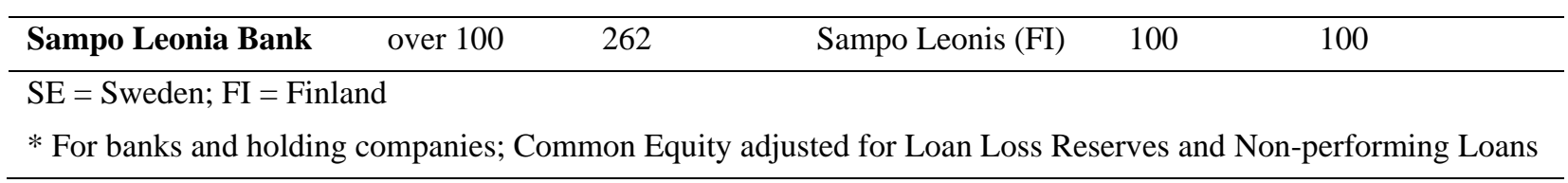

Source: Standard and Poor's, Central Bank

The pragmatic measures and structures which small Estonia had followed in its bank privatisations set-ups, and these as a vital element of its economic transition, have been described as Thatcherite in approach.(Note 22) It had been an approach which brought the country to a stage where totrally new concerns were now occupying its authorities from 2001 onwards. These were all related to the declared objective of getting the country into the EU. (Note 23)

The country's new priorities on the financial sector now included, inter alia, the building of a well-functioning securities market, where visibility and market liquidity would be regular features, and the bringing into effective operation an integrated financial supervisory structure, covering not only banking but also securities activities and insurance.(Note 24)

\section{Post-Reform Evolution and Conclusions}

(a) These indeed vastly different accounts of how Romania's and Estonia's financial services sectors moved from under total state ownership into the private sector, inevitably brought in their wake sharp contrasts in EBRD economic classifications in 2001 for the two countries' progress on large-scale enterprise privatisation, on (specifically) banking reform, on interest rate liberalisation, on securities market operating, and on non-bank financial institution reform. These classifications are shown in Table 9, and further interpreted below.

Table 9. Transitional progress -2001

\begin{tabular}{|c|c|c|}
\hline & Romania & Estonia \\
\hline Large-scale enterprise privatisation & $3+$ & $\underline{4}$ \\
\hline Financial Institutions: & & \\
\hline $\begin{array}{l}\text { Banking reform and interest rate } \\
\text { Liberalisation }\end{array}$ & $3-$ & 4- \\
\hline $\begin{array}{l}\text { Securities markets and non-bank } \\
\text { Financial institutions }\end{array}$ & 2 & 3 \\
\hline
\end{tabular}

Source: EBRD Transition Report, 2001

(b) The 3+ grading which Romania earned in respect of the privatisation process of its larger enterprise sector, meant that a level of over 25 per cents of the assets of these enterprises had moved into private hands, or was in the process of being privatised. The process in the latter case was considered as having reached a stage where the state had effectively ceded its ownership rights, but major issues regarding corporate governance remained.

For the same process, the 4 grading earned by Estonia reflected the fact that the percentage of such privatised assets was over 50 per cent, and that significant corporate governance progress had taken place in these enterprises.

(c) By 2001 Romania was considered by the EBRD as having made "substantial" progress in establishing bank solvency, and in the creation of a framework for prudential supervision and regulation. The country now had full interest rate liberalisation, with only restricted situations of preferential access to cheap refinancing. The 3-grading also reflected the EBRD's view that the levels of lending to private enterprises, and of the presence of private banks, were significant.

On the other hand, Estonia's now higher gradings meant that the standards and performance norms in that country's banking system were those equivalent to advanced industrial economies, with full convergence of banking laws and regulations towards the standards of the Bank of International Settlements (BIS). In the eyes of the EBRD, Estonia now had a banking system where banking competition functioned well and was prudently supervised. Significant term lending to private enterprise, and substantial financial deepening, had also become welcome aspects of the privatised Estonian banking sector. 
(d) Romanian, and Estonian, securities markets, and the role and levels of activity of non-financial institutions, showed a number of areas where in both countries progress was slow. The formation and development of securities exchanges, and similarly so that of market-makers and brokers, was a long uphill struggle in Romania. Trading in government paper and in other securities was at low levels, and public perception of such business was no doubt effected by the existing rudimentary framework for issuance and trading in securities.

In Estonia the issuing of securities by private enterprises was more substantial. The market was better protected through the existence of formal share registries, secure clearance and settlement procedures, and an acceptable level of protection of minority shareholders' rights. Estonia also earned a positive grading from the EBRD for an acceptable associated regulatory framework covering emerging non-bank financial institutions, such as investment funds, private insurance and pension funds, and leasing companies.

These differing pictures of the manner of SOB privatisation in these two formerly soviet-controlled countries could possibly suggest, by way of a very general conclusion that in both countries FSI privatisation was at a certain point accepted with the necessary positive and correct culture. As seen they however had had substantially different starting-off bases and evolutionary patterns. (Note 25)

\section{References}

Aldcroft, D. H., \& Morewood, S. (1995). Economic Changes in Eastern Europe since 1918, p. 221. Edward Elgar, Cheltenham.

Business Central Europe (BCE). (1998, June). Romania's stock market - quantity not quality.

Business Central Europe. (1999, July/Aug). BCE, 6(63), 37.

Business Central Europe. (1999, May). BCE, 6(61), 47.

Cook, J. (1998). Romanian bank privatisation forced sale. BCE, 6(49), 59-60.

Cook, J. (1998). The big test. BCE, 6(52), 27.

EBRD. (1994). Transition Report, p 127.

EBRD. (1994, October). Transition Report, p 23.

EBRD. (2001). Transition Report, 138.

ECB. (2001, December 6-7). Financial Sector Developments and Convergence in Accession Countries: An Overview, p 15. Background paper for the Eurosystem Seminar with Accession Countries' Central Banks, Berlin.

Jones, C. (1992). Privatisation in East Europe and the former Soviet Union. Financial Times Business Enterprises, London.

Kell, K. (1999, July 7). Eesti Bank Head of Information.

Lieven, A. (1998, April 3). Romania banks on EBRD to smooth the privatisation process. FT.

Lindgren, C. J., Garcia, G., \& Saal, M. I. (Eds.). (1996). Bank Soundness and Macroeconomic Policy. IMF, Washington, DC.

Mellow, C. (2016, May). Breaking Away, pp. 20-23, 72. Retrieved from Institutional Investor.com

NBR. (1992). Quarterly Bulletin, N.3, p 11.

Pank, E. (1993). Annual Report, p 18.

Reuters. (2004). Schroeder sees Romania as closing EU talks this year. The Times, August 14, p.19.

Schultz, T. (1996). Baltic banking - Estonian disciples. BCE, 6(32), 54-55.

The Economist. (2001). Europe in Figures, p. 81.

Zile, R., et al. (2000). For full treatment of development of the Latvian banking system vide Chapter IV by Helmuts Ancans. Latvia Entering the XXIst Century. Nacionalais Medicdinas Apgads Ltd, Riga. 


\section{Notes}

Note 1. A "core-investor-size" stake is defined as one which is larger than $25 \%$ of total equity in a bank.

Note 2. In evaluating these elements one has to make allowance for the fact that the process evolved to a point where reality became one where very few SOBs remained available in the CEECs for privatisation, or indeed even for M \& As.

Note 3. Ceausescu's legacy was an economy plagued by an inefficient industrial structure and an almost totally obsolete capital stock, a completely disorganised system of production and distribution, a collectivised agricultural sector, a decaying infrastructure, and a population whose living sdtandards had been forced steadily down to a level where bare necessities - food, heating, electricity, and medical attention - were hard to come by. There is little doubt that the initial obstacles to reform in Romania were far worse than those faced by the other reforming East European countries (Denekas and Khan, 1991, p 30).

Note 4. “Bank, or Wreck?" - BCE, Vol 6, No. 52, p 27.

Note 5. Final sale negotiations were actually the preserve of the State Ownership Fund, the government agency charged with privatising state assets.

Note 6. "Eastern Europe", as a political term, belongs firmly to the postwar period. Pre-war geographers had placed Czechoslovakia, Eastern Germany, Hungary, and Poland, in Central Europe. Bulgaria, Romania, and Yugoslavia were clustered in Southern Eastern Europe (or the Balkans). Above all Eastern Europe represented a geopolitical bloc centred on Moscow. The Soviet superglue began to be applied to all states bar Yugoslavia when these were referred to by Soviet spokesmen as the "people's democracies" of Eastern Europe.

Note 7. Costly advertising by the Romanian State Ownership Fund for "share sales by negotiation", for sales of shares by direct negotiation", for sales "through negotiation with final offers", sales "through negotiation", and for "management and financing" of state entities contracts, appeared with assiduity in the Financial Times, The Economist, and other specialist readership media in 1999 and 2000.

Note 8. E.g. a parliamentary commission claimed that in 1998 a $35 \%$ stake in national phone firm RomTelecom to Greece's OTC was sold below market value. Officials also claimed that the sale violated the law by including a $10 \%$ commission fee to unnamed parties.

Note 9. E.g. Chemical Bank (US), Societe' Generale (France), Franco Romanian Bank, Frankfurt Bucharest Bank, Egypt-Romania Bank.

Note 10. At the June 1993 meeting of the European Council in Copenhagen four conditions were agreed upon and stipulated for future applicant countries to be accepted as EU members. These were: (1) stability of institutions, guaranteeing democracy, rule of law, human rights, and respect for and protection of minorities, (2) the existence of a functioning market economy, (3) capacity to cope with competitive pressures and market forces within the EU, and (4) the ability to take on the obligations of membership, including adherence to the aims of political, economic, and monetary union, with this implying full acceptance of the EU's acquis communitaire.

Note 11. The list of German firms which benefited from those deals included EADS Defence \& Communications Systems (a $€ 650 \mathrm{mn}$ contract for implementing an integrated homeland state border security system), Siemens AG, and the ABB-AREVA joint Swedish-German consortium.

Note 12. The Bank of Estonia was established as a central bank in 1990, but the local branch of the Soviet Gosbank continued to carry out most central bank functions until January 1992. The Estonian central bank was granted independence in 1993.

Note 13. The term is here used in the IMF context which distinguishes between "crisis" and "significant". The IMF (vide Sandararajan and Balino 1991) methodology refers to cases where there were runs or other substantial portfolio shift collapses of financial firms, or massive government interventions, as being "crises". On the other hand extensive unsoundness short of a crisis is termed "significant" (Lindgren et al, 1996 "Bank Soundness \& Macroeconomic Policy", IMF, vide Note 31).

Note 14. These had included the establishment of specialised state banks and some new commercial banks, including some private ones.

Note 15. At the end of the year it was the smallest commercial bank in Estonia with $0.4 \%$ of all bank assets.

Note 16. It was events in neighbouring Latvia that accelerated plans for a new deposit insurance structure. From July 
1996 deposits of up to $\$ 10,000$ started being insured, in October 1998 compensation of up to $90 \%$ of deposits or to a maximum of Ek20,000 was introduced, and protection for limited deposits of legal entities came in in 2000.

Note 17. As stated by Kaja Kell (1999) (op cit).

Note 18. The share of deposits held by individuals among total deposits in commercial banks was $24 \%$ at end May 1995 (Hungary: 55.1\%, Dec 1994). Based on balance sheet total the market share of ESB was 16.3\% at end May 1995. The increase in ESB's balance sheet total over 12 months to March 1995 was $89.5 \%$, slightly above the average increase for the four large banks (Hungary OTP bank market share at end of 1994: +/- 31\%). The market share of ESB in individuals' deposit market was $43.2 \%$ in May 1995. The combined share of the other four large players was $36.4 \%$. The ratio between cash, and non-government domestic currency deposits in banks was roughly 1:2 in May 1995 (Hungary 1:3.5 in June 1995, and probably even higher if foreign currency deposits and foreign cash are taken into account).

Note 19. Including balanced budgeting, pegging the kroon to the Deutsche Mark, and a flat rate of tax.

Note 20. Based on Market shares in the 1995-1997 period.

Note 21. More than 800,000 (in a total population of $1.5 \mathrm{mn}$ ) were on issue in 1998 .

Note 22. Vijai Maheshwari (2001) describes Thatcherism as a fashionable past Estonian characteristic, before going on to add that "[But] now looming EU accession is nudging the government to reconsider its social agenda long ignored in the drive for reform and privatisation." - BCE, Vol 8, No. 82, pp 45-46.

Note 23. Estonia, along with the Czech Republic, Malta, and Cyprus, was in August 2003 described as being the best prepared from amongst the ten countries scheduled to become EU members with effect from $1^{\text {st }}$ May 2004. This assessment was made by EU Commissioner for Regional Policy Michael Barner.

Note 24. Similar to Malta's own Malta Financial Services Authority (MFSA), Estonia introduced such a structure in 2002.

Note 25. A synthesising matrix of the main elements of these, and other countries', financial services privatisation experiences appears in Consiglio J.A. (2006), "Financial Services Privatisation in the Central and Eastern European Countries: Relating the Analysis to the Experience of Malta" - (University of Malta, $\mathrm{PhD}$ thesis, unpublished). An Appendix showing the Key Financial Sector Privatisation Legal Measures enacted in Romania between 1990 and 1998 is also featured. 